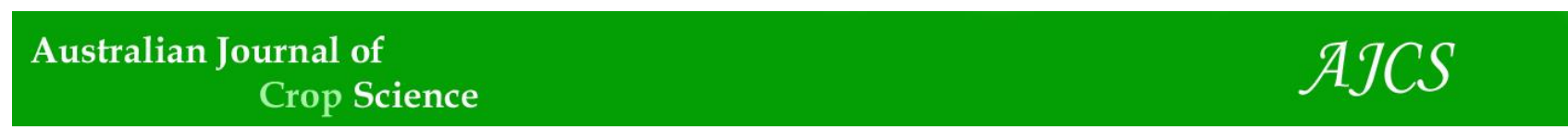

AJCS 12(06):909-914 (2018)

ISSN:1835-2707

doi: 10.21475/ajcs.18.12.06.PNE922

\title{
Watermelon fruit production and characterization affected by molybdenum (Mo) and other micronutrient fertilization
}

\author{
Elaine Heberle ${ }^{1}$, Daniela Vieira Chaves ${ }^{1 *}$, Renato Falconeres Vogado ${ }^{2}$, Firmino Nunes de Lima ${ }^{3}$, Joelma \\ Francisca de Moura Lima ${ }^{4}$, Fernando Luiz Finger ${ }^{5}$
}

\author{
${ }^{1}$ Federal University of Piauí (UFPI), Campus Professora Cinobelina Elvas (CPCE), Bom Jesus, 64900-000, Piauí, Brazil \\ ${ }^{2}$ Federal University of Paraíba (UFPB), Areia, Paraíba, Brazil \\ ${ }^{3}$ Federal University of Brasília (UNB), Brasília, Brazil \\ ${ }^{4}$ Federal Institute of Maranhão (IFMA), São Raimundo das Mangabeiras, Maranhão, Brazil \\ ${ }^{5}$ Federal University of Viçosa, (UFV), Viçosa, Minas Gerais, Brazil
}

*Corresponding author: chavesdv@ufpi.edu.br

\begin{abstract}
Micronutrients are essential for the development of plants and may affect the quantity and quality of the products of interest. This study aimed to evaluate the effects of foliar fertilization with molybdenum and other micronutrient on 'Olímpia' watermelon fruit yield and quality. The experiment was carried out following a randomized block design, with treatments in a $4 \times 2$ factorial scheme, for molybdenum doses $\left(0,15,30\right.$, and $\left.60 \mathrm{~g} \mathrm{Mo} \mathrm{ha}^{-1}\right)$ and Kit presence or absence, with four replications. The number of fruits per plant, yield per plant, commercial productivity, average fruit mass, longitudinal and transverse diameters, peel thickness, and pulp yield were evaluated. Molybdenum foliar fertilization increased the yield per plant and the fruit diameters, with the best results at dose of $30 \mathrm{~g} \mathrm{Mo} \mathrm{ha}^{-1}$. The Kit promoted higher productivity per plant (25.7\%), fruits with higher pulp yield (5.3\%) and lower peel thickness (11.07\%). Joint molybdenum and Kit application increased watermelon fruit pulp yield by $5.7 \%$ at $30 \mathrm{~g}^{\mathrm{Mo}} \mathrm{ha}^{-1}$, and up $8.4 \%$ at higher doses. Foliar fertilization with $30 \mathrm{~g} \mathrm{Mo} \mathrm{ha}^{-1}$ and other micronutrients improve the 'Olímpia' watermelon fruit yield and quality being recommended to producers.
\end{abstract}

Keywords: Citrullus lanatus; Curcurbit; Foliar fertilization; Foliar Kit; Fruit quality.

Abbreviations: $\mathrm{CP}_{-}$commercial productivity; LD_longitudinal diameter; MFM_mean fruit mass; Mo_molybdenum; NP_number of fruits per plant; PT_peel thickness; PP_productivity per plant; PY_pulp yield; TD_transverse diameter.

\section{Introduction}

The watermelon plant (Citrullus lanatus) is a cucurbit with great socioeconomic expression and well-adapted to cultivation in Brazil. However, the low yield is mainly due to inadequate fertilization management (Barros et al., 2012) According to Vidigal et al. (2009), the nutrients most required by the crop are K; N; Ca; P; and S. Nevertheless, nutritional balance also depends on micronutrients, some of which play major roles in plant metabolism. Thus, it is worth noticing molybdenum (Mo), due to its association with nitrogen (N) metabolism and enzymatic complexes, nitrogenase and nitrate reductase (Schwarz et al., 2009; Duval et al., 2014). The element can also be linked to other enzymes responsible for important functions in plants, such as xanthine dehydrogenase, aldehyde oxidase and sulfite oxidase (Mendel and Hansch, 2002). The efficiency of molybdenum fertilization has been proven in several crops, mainly legumes. Biscaro et al. (2011) observed increases in the relative chlorophyll index, yield components, and seed features of bean cultivated with $80 \mathrm{~g} \mathrm{Mo} \mathrm{ha}^{-1}$ by seed treatment and foliar fertilization in Cerrado soil. However, the ideal supply of Mo seems to be dependent on the species and age of the plant (Pessoa et al., 2000; Quaggio et al., 2004).

Several formulated products or kits for foliar fertilization, containing macro and micronutrients, plant regulators and amino acids, among others, have been used by producers aiming at nutritional balance and increased productivity. Micronutrient fertilization supplementation is considered essential for increased yield and improved fruit chemical composition (Naga Sivaiah et al., 2013). Carvalho et al. (2012) observed increased nutrient content in soybean plant leaves under application of three types of foliar kits with micronutrients. Naga Sivaiah et al. (2013) observed that the application of micronutrients led to greater growth and tomato production. The authors concluded that the increase in yield is related to the increase of photosynthesis, which promotes greater accumulation of carbohydrates favoring plant growth, retention of flowers and fruits, and number and weight of fruits.

Foliar fertilization is an efficient technique because the nutrients are absorbed rapidly, supplying the needs of 
plants, increasing the growth rates, the production and the quality of the products (Mocellin, 2004).

Information on the effects of Mo and micronutrients on watermelon crops is rare. Thus, this study aimed to evaluate the effects of fertilization with molybdenum and other micronutrient on 'Olímpia' watermelon fruits yield and quality.

\section{Results and Discussion}

The variance analysis (Table 1) showed the individual effect of the Mo dose factor on the number of fruits per plant (NFP), commercial productivity (CP), mean of fruit mass (MFM), and longitudinal (LD) and transverse diameters (TD). In turn, the foliar kit application affected productivity per plant (PP), peel thickness (PT), and pulp yield (PY). There was interaction effect of molybdenum doses and foliar kit only for pulp yield of 'Olímpia' watermelon fruits.

\section{Molybdenum effect}

Molybdic foliar fertilization affected both fruit yield and quality as function of doses. The number of fruits per plant increased linearly as the Mo dose applied increases, reaching of 1 fruit per plant in the $60 \mathrm{~g} \mathrm{Mo} \mathrm{ha}^{-1}$ dose, representing $38 \%$ increase when compared to control (Fig $1 \mathrm{~A})$. However, the best result observed is still below that reported by Leão et al. (2008), who obtained 1.4 fruits per plant when testing increasing NPK fertilization doses; by Cavalcante et al. (2010), who reported 1.33 fruits per 'Crimson Sweet' watermelon plant produced with $10 \mathrm{~L} \mathrm{pit}^{-1}$ of bovine and goat manure; and by Ramos et al. (2009), who harvested 4.4 fruits per 'Sugar Baby' watermelon plant when testing various densities and varieties.

The increased of fruits production may be related to increased formation of floral organs promoted by the molybdic fertilization of beans, as proposed by Pires et al. (2004), and observed by Jião et al. (1992), in vines cultivated with increased Mo doses, which lead to an increased number of fruits.

The commercial productivity (Fig 1B) and mean fruit mass (Fig 1C) showed a negative quadratic tendency, being reduced due to increasing molybdenum doses applied. The best results were obtained when used the recommended 30 $\mathrm{g} \mathrm{Mo} \mathrm{ha}{ }^{-1}$ dose. It can be noticed that, when the plants did not receive molybdic fertilization, they reached the maximum commercial productivity of $27.44 \mathrm{tha}^{-1}$, with small decreases in the doses of 15 and $30 \mathrm{~g} \mathrm{Mo} \mathrm{ha}^{-1}$ and a strong reduction in the dose of $60 \mathrm{~g} \mathrm{Mo} \mathrm{ha}^{-1}$.

Mean fruit mass reached the maximum of $7.14 \mathrm{~kg}$ in the absence of Mo fertilization, showing a behavior similar to commercial yields, since productivity is correlated with the weight of fruits produced by area (Queiroga et al., 2007), in addition to consider that only fruits weighing $5 \mathrm{~kg}$ or more are sold. Thus, although the number of fruits per plant has increased as a function of molybdic fertilization, this did not reflect higher commercial productivity, demonstrating that Mo helps promoting the formation of more fruits, but do not always reach the size and weight wanted by the consumer market.

Decrease in these variables in the higher Mo doses may be related to the fact that higher Mo concentrations can cause inhibitory effects of nitrate reductase enzyme and chloroplast formation, for reasons not yet known (Weng et al., 2009), and decreased commercial productivity can result in high doses of this micronutrient. However, the lowest commercial productivity of $24 \mathrm{t} \mathrm{ha}^{-1}$, observed at the highest Mo dose, was still above the Brazilian national productivity and in the state of Piauí, $23 \mathrm{t} \mathrm{ha}^{-1}$ and $22.574 \mathrm{t} \mathrm{ha}^{-1}$, respectively (IBGE, 2014), and the $22.9 \mathrm{t} \mathrm{ha}^{-1}$ obtained by Leão et al. (2008) by testing increasing doses of chemical and organic fertilizers. Yet, it was far below the $40.43 \mathrm{t} \mathrm{ha}^{-1}$ observed by Barros et al. (2012), in 'Crimson Sweet' watermelon grown with various $\mathrm{N}$ doses.

Since Mo interferes with $\mathrm{N}$ metabolism, absorbed as nitrate, will require the reduction to nitrite and conversion to ammonia, in order to be incorporated into the proteins (Tomatsu et al., 2007), it is indispensable to provide adequate Mo supply to improve $\mathrm{N}$ use, attributing the nitrate reductase activity. A low activity of this enzyme can lead to decreased growth, altered performance, and reduced fruit formation (Graham et al., 2005). Thus, the importance of this element for the watermelon crop is well reported, as its application affects fruit growth and, consequently, its commercial value.

\section{Foliar kit effect}

Among the production parameters evaluated, the foliar kit had effects only on productivity per plant, with productivity of $7.01 \mathrm{~kg}$ plant ${ }^{-1}$, while in its absence the yield was $5.21 \mathrm{~kg}$ planta $^{-1}$, a reduction about $25.82 \%$ (Table 1 ). The application or not of the foliar kit did not contribute to increase the number of fruits $\left(0.78\right.$ fruits plant $\left.{ }^{-1}\right)$, commercial productivity $\left(26.30 \mathrm{~kg} \mathrm{ha}^{-1}\right)$, mean fruit mass $(6.838 \mathrm{~kg}$ fruit $\left.{ }^{1}\right)$, longitudinal diameter $(23.59 \mathrm{~cm})$ and transverse diameter $(35.57 \mathrm{~cm})$.

Regarding fruit characterization, the kit did not affect the size, determined by longitudinal and transverse diameters (Table 1 and Fig 2), but caused changes in peel thickness and pulp yield (Table 1). Plants that received the kit produced fruits with thinner peel (10.9\%) and higher pulp yield (5.67\%). The pulp yield of 'Olímpia' watermelon fruits was $60.0 \%$ and $64.35 \%$ in the fruits without and with kit application, respectively. These values are higher than those observed in the cultivars 'Fairfax' (58.46\%) and 'Sugar Baby' (58.27\%) by Lima Neto et al. (2010).

These are significant quality attributes for watermelon fruits, because it is desired to have few peel and more pulp, which is the part consumed (Ramos et al., 2009). However, fruits with very low peel thickness are more sensitive to mechanical damage during transport and storage, thus peel must have a thickness that upholds handling without damaging the fruits (Silva et al., 2007).

\section{Interaction of molybdenum and foliar kit effects}

Only pulp yield was affected by interaction between the Mo doses and foliar kit (Table 1). However, it showed different responses when applying or not the kit as a function of molybdic fertilization doses (Fig 3). In absence of the kit, there was a quadratic tendency, with increased pulp yield values at the intermediate doses and subsequent reduction. While in presence of the kit, there was a tendency of increase, followed by stable values. 
Table 1. Number of fruits per plant (NFP); productivity per plant (PP); commercial productivity (CP); mean fruit mass (MFM); longitudinal (LD) and transverse diameter (TD); peel thickness (PT) and pulp yield (PY) of 'Olímpia' watermelon as a function of molybdenum doses and Kit

\begin{tabular}{ccccccccc}
\hline VF & NFP & PP & CP & MFM & LD & TD & PT & PY \\
\hline Mo $^{1}$ & $6.222^{* *}$ & $0.624^{\text {ns }}$ & $3.049^{*}$ & $3.050^{*}$ & $3.486^{*}$ & $4.061^{*}$ & $2.620^{\text {ns }}$ & $1.745^{\text {ns }}$ \\
\hline$M S D$ & 0.255 & 2.860 & 3.591 & 0.934 & 3.437 & 1.898 & 1.723 & 2.376 \\
\hline Kit $^{1}$ & $0.222^{\text {ns }}$ & $6.05^{*}$ & $1.39^{\text {ns }}$ & $1.39^{\text {ns }}$ & $2.29^{\text {ns }}$ & $0.04^{\text {ns }}$ & $10.45^{* *}$ & $31.65^{* *}$ \\
Absent & $0.77 \mathrm{a}$ & $5.21 \mathrm{~b}$ & $25.76 \mathrm{a}$ & $6.70 \mathrm{a}$ & $40.93 \mathrm{a}$ & $35.52 \mathrm{a}$ & $12.92 \mathrm{a}$ & $60.92 \mathrm{~b}$ \\
Present & $0.80 \mathrm{a}$ & $7.01 \mathrm{a}$ & $26.84 \mathrm{a}$ & $6.98 \mathrm{a}$ & $42.26 \mathrm{a}$ & $35.62 \mathrm{a}$ & $11.49 \mathrm{~b}$ & $64.35 \mathrm{a}$ \\
\hline MSD & 0.137 & 1.514 & 1.901 & 0.494 & 1.819 & 1.898 & 0.912 & 1.258 \\
\hline MoxKit $^{1}$ & $2.000^{\text {ns }}$ & $2.967^{\text {ns }}$ & $1.255^{\text {ns }}$ & $1.255^{\text {ns }}$ & $1.244^{\text {ns }}$ & $1.608^{\text {ns }}$ & $0.326^{\text {ns }}$ & $3.666^{*}$ \\
\hline CV(\%) & 24.00 & 33.93 & 9.90 & 9.90 & 5.99 & 3.87 & 10.24 & 2.75 \\
\hline
\end{tabular}

VF: Variation factor, MSD: minimum significant difference; CV (\%): coefficient of variation. ${ }^{1}$ : Test $\mathrm{F} ;{ }^{\text {ns }}$ : not significant; " and " : significant of $p<0.05$ and $p<0.01$, respectively, by the $\mathrm{F}$ test. For the Kit factor, average values followed by the same letter in the column do not differ from each other by the Tukey test ( $\mathrm{p}<0.05$ ).
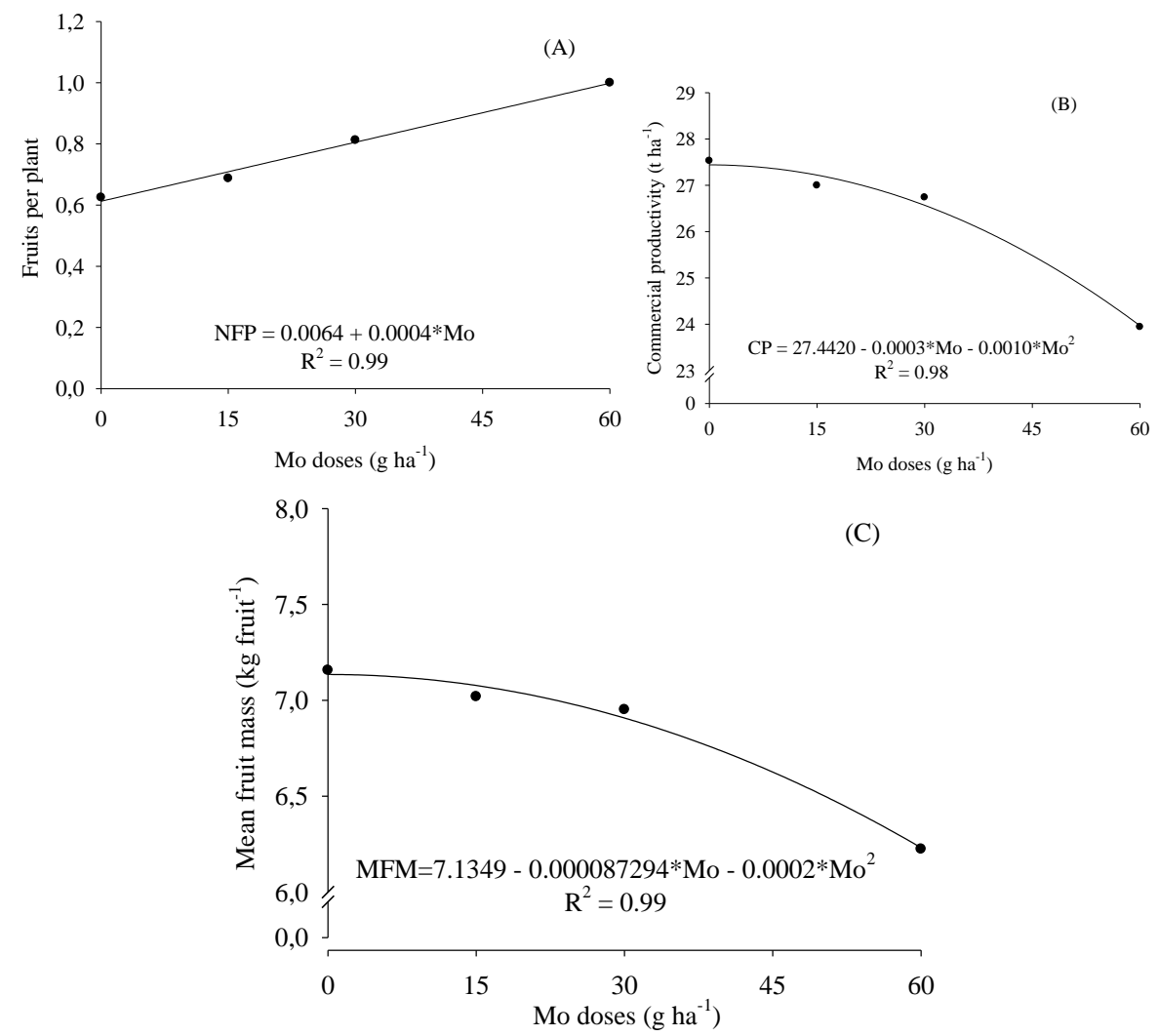

Fig 1. Response of the number of fruits per plant (A), commercial productivity (B) and mean fruit mass (C) of 'Olímpia' watermelon fruits as a function of increasing molybdenum doses.
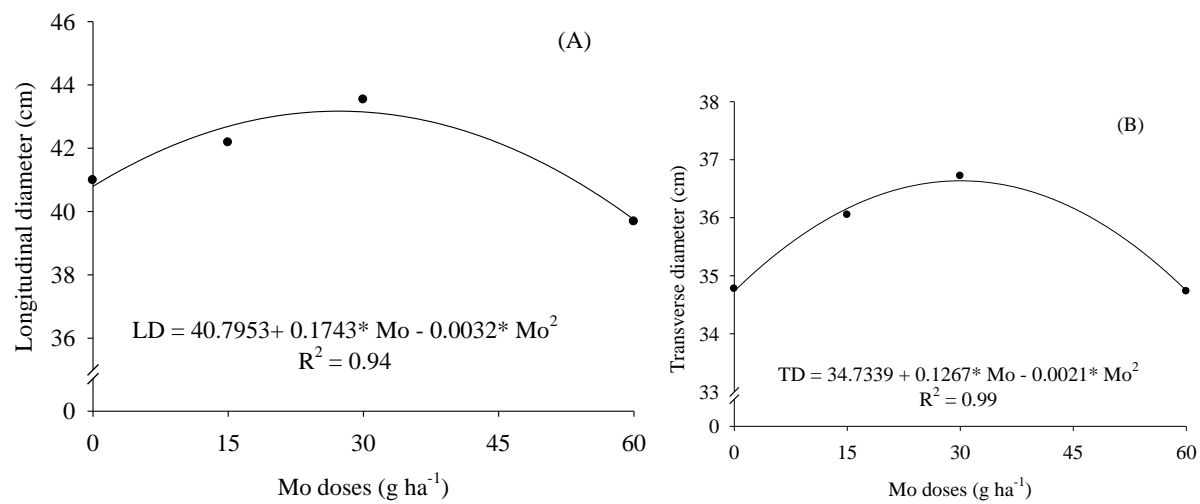

Fig 2. Longitudinal (A) and transverse diameters (B) of 'Olímpia' watermelon fruits as a function of increasing molybdenum doses. 


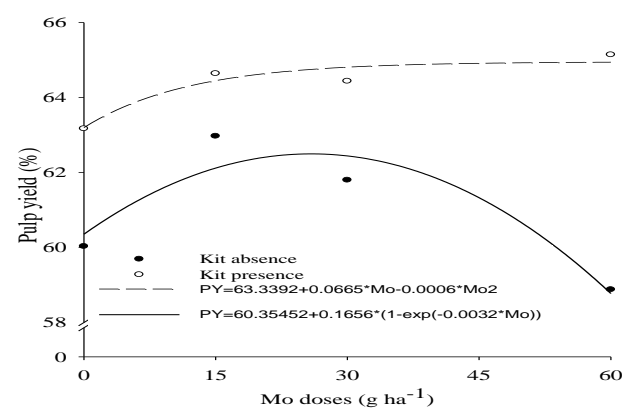

Fig 3. Response of the pulp yield of 'Olímpia' watermelon fruits as a function of increasing molybdenum doses and foliar kit.

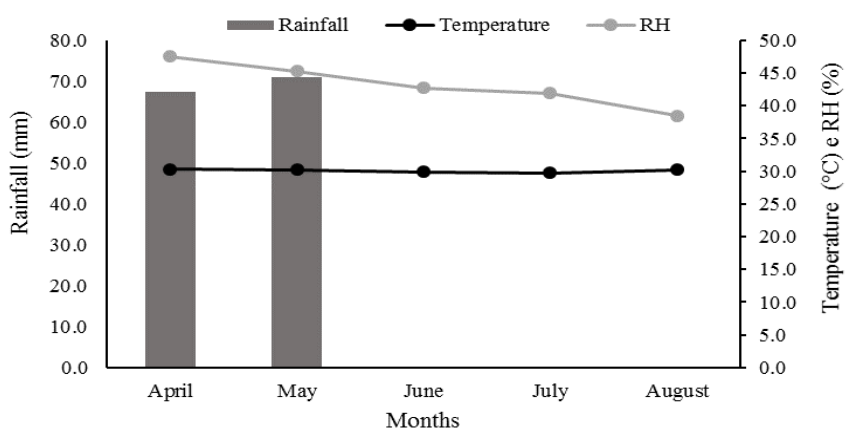

Fig 4. Rainfall, average air temperature and air humidity during the experimental period. Bom Jesus - Pl, Brazil.

The foliar kit may have helped to obtain more uniform distribution of nutrients, contributing to higher nutritional balance in these plants, key for growth, development, and quality of the watermelon fruits produced. Since the applications of the kit were performed during fruiting, perhaps their nutrients were mainly directed to fruit formation, preferential drains in this crop (Grangeiro and Cecílio Filho, 2005).

Regardless of the Mo dose, fruits cultivated with the kit had more pulp than in its absence. Perhaps, molybdenum fertilization has provided the plants with conditions to achieve the best use of nutrients present in the kit or improved the efficiency of enzymatic metabolism, especially related to $\mathrm{N}$, as the latter directly influences fruit quality.

According to Gupta et al. (1990), molybdic fertilization up to a certain limit causes an increase in foliar area due to greater plant response to $\mathrm{N}$ use, absorbed both by soil and through the kit, which implies increased foliar $\mathrm{N}$ content, as observed in lettuce (Resende et al., 2012). Such an increase in $\mathrm{N}$ can lead to higher chlorophyll content and products of photoassimilation (Taiz and Zeiger, 2013), affecting fruit production and characterization.

From the results of this work, Mo doses up to $30 \mathrm{~g} \mathrm{ha}^{-1}$ have promoted increase in number of fruits per plant, commercial productivity, average mass, and fruit size. Foliar kit application has promoted higher yield per plant, fruits with lower peel thickness and higher pulp yield. Combined application of Mo and foliar kit increased the pulp yield of 'Olímpia' watermelon fruits. Foliar fertilization with a Mo dose of $30 \mathrm{~g} \mathrm{ha}^{-1}$ and foliar kit application improve the production and quality of 'Olímpia' watermelon fruits.

\section{Materials and Methods}

\section{Characterization of experimental area and plant material}

The experiment was conducted within the period from April to August at the Horticulture Experimental Area and in the Plant Breeding Laboratory, in the Campus Professora Cinobelina Elvas of the Federal University of Piauí (UFPI), Bom Jesus, Piauí, Brazil (0904'28" S, 4421'31" W, at 277 $\mathrm{m})$.

During the experimental period, monthly rainfall averages of $70 \mathrm{~mm}$ were observed in April and May, with temperature of $30{ }^{\circ} \mathrm{C}$ and relative air humidity ranging from $50 \%$ to $38 \%$ (Fig 4).

The soil in the experimental area is classified as Dystrophic Yellow Latosol, with sandy-clay texture, presenting these features in the $0-20 \mathrm{~cm}$ depth profile: $\mathrm{pH}$ (water) $=5.78 ; \mathrm{Ca}^{2+}$ $=2.8 \mathrm{cmol}_{\mathrm{c}} \mathrm{dm}^{-3} ; \mathrm{Mg}^{2+}=1.2 \mathrm{cmol}_{\mathrm{c}} \mathrm{dm}^{-3} ; \mathrm{K}^{+}=84 \mathrm{mg} \mathrm{dm}^{-3}$; sum of bases $=4.22 \mathrm{cmol}_{\mathrm{c}} \mathrm{dm}^{-3} ; \mathrm{H}+\mathrm{Al}^{3+}=3.3 \mathrm{cmol}_{\mathrm{c}} \mathrm{dm}^{-3}$; CTC $=7.52 \mathrm{cmol}_{\mathrm{c}} \mathrm{dm}^{-3} ; \mathrm{P}$ (Melich) $=29.6 \mathrm{mg} \mathrm{dm}^{-3} ; \mathrm{S}=8.7 \mathrm{mg}$ $\mathrm{dm}^{-3} ; \mathrm{Na}^{+}=9 \mathrm{mg} \mathrm{dm}{ }^{-3} ; \mathrm{Zn}=4.5 \mathrm{mg} \mathrm{dm}{ }^{-3} ; \mathrm{Mn}=10.7 \mathrm{mg} \mathrm{dm}^{-3} ;$ $\mathrm{B}=0.23 \mathrm{mg} \mathrm{dm}^{-3} ; \mathrm{Mo}=0.07 \mathrm{mg} \mathrm{dm}^{-3} ; \mathrm{Cu}=0.2 \mathrm{mg} \mathrm{dm}^{-3} ; \mathrm{Fe}=$ $56.8 \mathrm{mg} \mathrm{dm}^{-3}$; Co $=0.06 \mathrm{mg} \mathrm{dm}^{-3}$; aluminum saturation $=$ $2.32 \%$; base saturation $=56.09 \%$; and $\mathrm{Mo}=15 \mathrm{~g} \mathrm{dm}^{-3}$.

The area was prepared with plowing and harrowing 60 days before sowing, done directly in the pits, with $1.3 \mathrm{~m}$ spacing between pits and $2 \mathrm{~m}$ between rows, using three hybrid 'Olímpia' watermelon seeds per pit. At 15 days after sowing (DAS), thinning was done, leaving 2 plants pit $^{-1}$ and keeping a population of 1,785 plants $\mathrm{ha}^{-1}$. 
A drip irrigation system was used, with water supply according to crop needs at the various stages, with average $\mathrm{Kc}$ of 0.67 (Miranda et al., 2004) and average flow of $1.26 \mathrm{~L}$ $\mathrm{h}^{-1}$. Fertilization was partly applied ( $30 \%$ of $\mathrm{N}$ and $40 \%$ of $\mathrm{K}$ ) to the pits and the remainder to the coverage, using ammonium sulfate $(21 \%$ of $\mathrm{N})$ and potassium chloride $(60 \%$ of $\mathrm{K}_{2} \mathrm{O}$ ), supplied in a circular range within the canopy projection, at 15; 30 and 45 DAS (Ribeiro et al., 1999).

\section{Experimental design and treatments}

A randomized block design was adopted, with treatments arranged in a $4 \times 2$ factorial scheme, corresponding to four Mo doses $\left(0 ; 15 ; 30\right.$; and $\left.60 \mathrm{~g} \mathrm{Mo} \mathrm{ha}^{-1}\right)$ and foliar kit absence or presence, with 4 replications and 4 plants per plot.

Molybdic fertilization was done by using the commercial product FortSeed Dry ( $30 \% \mathrm{Mo})$, applied by foliar spraying at the emergence of the first branch, at 20 DAS. The foliar Kit consisted of the following commercial products and respective dosages: Risa Cerrado $\mathrm{Dry}^{\circ}=1 \mathrm{~kg} \mathrm{ha}^{-1}$ (10\% of K; $16 \%$ of $\mathrm{S} ; 1 \%$ of $\mathrm{Mg} ; 3.5 \%$ of $\mathrm{Zn} ; 1.5 \%$ of $\mathrm{B} ; 15 \%$ of $\mathrm{Mn} ; 0.3 \%$ of CU EDTA); Phisiocrop $=500 \mathrm{~mL} \mathrm{ha}{ }^{-1}(7.5 \%$ of $\mathrm{N} ; 2.5 \%$ of humic acids; $12.5 \%$ of fulvic acids; $5.35 \%$ of total amino acids; $4.39 \%$ of free amino acids; $6 \%$ of total organic carbon); Kalium Phós $=800 \mathrm{~mL}$ ha $^{-1}\left(30 \%\right.$ of P; $20 \%$ of $\mathrm{K}_{2} \mathrm{O}$ ); salt 12 $00-44=1 \mathrm{~kg} \mathrm{ha}^{-1}$; Cab Dry $=1 \mathrm{~kg} \mathrm{ha}^{-1}\left(2 \%\right.$ of $\mathrm{K}_{2} \mathrm{O} ; 20 \%$ of $\mathrm{Ca}$; $4 \%$ of B); and $\mathrm{Li} 700^{\circ}=100 \mathrm{~mL} \mathrm{ha}{ }^{-1}$ (lecithin, propionic acid, nonionic surfactant). The application was done by foliar spraying at $33 ; 37 ; 42 ; 47 ; 53$ and 68 DAS.

\section{Data collect}

The fruits were harvested individually at the harvest maturity, determined by dryness of the tendril closest to the peduncle, external peel color change (Barros et al., 2012) and hollow sound to the touch. Harvesting of each plot were considered together to determine the variables: Number of fruits per plant (NFP); Productivity per plant (PP): $\mathrm{kg} \mathrm{plant}^{-1}$; Commercial productivity (CP): determined by the weight of fruits with commercial quality ( $\geq 5 \mathrm{~kg}$ and no visible damage and defects) of the plot area, turned into $\mathrm{kg} \mathrm{ha}^{-1}$; Mean fruit mass (MFM): determined by the ratio between total mass and number of fruits with commercial quality, $\mathrm{kg} \mathrm{plant}^{-1}$; Longitudinal (LD) and transverse (TD) fruit diameters: $\mathrm{cm}$; Peel thickness (PT): measured using a digital caliper (Digimess ${ }^{\circledR} 0.01-300 \mathrm{~mm}$ ), in $\mathrm{mm}$; and Pulp yield (PY): obtained by the ratio between pulp mass and total fruit mass, expressed in \%.

\section{Statistical analysis}

The results underwent analysis of variance, the significant means for the qualitative factor were compared through the Tukey's test $(p \leq 0.05)$ and the quantitative factor by means of regression analysis, according to Banzatto and Kronka (2006), using The statistical softwares $R$ and SigmaPlot.

\section{Conclusion}

Foliar fertilization with $30 \mathrm{~g}$ Mo $\mathrm{ha}^{-1}$ and other micronutrients improve the 'Olímpia' watermelon fruit yield and quality being recommended to producers.

\section{Acknowledgments}

The authors thank the Piauí State Foundation for Research Support (FAPEPI), Brazilian National Council for Scientific and Technological Development (CNPq), Brazilian Coordination for the Improvement of Higher Education Personnel (CAPES), Federal University of Piauí (UFPI) and the FortGreen Company for their support.

\section{References}

Banzatto DA, Kronka SN (2006) Experimentação agrícola, 4rd edn. FUNEP, Jaboticabal. 237p.

Barros MM, Araújo WF, Neves LTBC, Campos Al, Tosin JM (2012) Produção e qualidade da melancia submetida a adubação nitrogenada. Rev Bras Eng Agr Amb. 16(10):1078-1084.

Biscaro GA, Freitas Junior NA, Soratto RP, Kikuti H, Goulart Junior SAR, Aggurre WM (2011) Nitrogênio em cobertura e molibdênio via foliar no feijoeiro irrigado cultivado em solo de Cerrado. Acta Sci-Agron. 33(4):665-670.

Carvalho ER, Rezende PM, Passos AMA, Oliveira JÁ (2012) Diagnose foliar e produtividade da soja em razão de doses e tecnologias de manufatura de fertilizantes formulados NPK. Rev Bras Cienc Agr. 7:402-408.

Cavalcante ÍHL, Rocha LF, Silva Júnior GB, Amaral FHC, Falcão Neto R, Nóbrega JCA (2010) Fertilizantes orgânicos para o cultivo da melancia em Bom Jesus - PI. Rev Bras Cienc Agr. 5:518-524.

Duval BD, Natali SM, Hungate BA (2014) What Constitutes Plant-Available Molybdenum in Sandy Acidic Soil? Commun Soil Sci Plan. 46:318-326.

Graham L, Ortiz-Monasterio I, Stangoulis J, Graham R (2005) Selenium concentration in wheat grain: is there suficiente genotypic variation to use in breeding. Plant Soil. 269:369380.

Grangeiro LC, Cecílio Filho AB (2005) Acúmulo e exportação de macronutrientes em melancia sem sementes. Hortic Bras. 23:763-767.

Gupta UC, Leblanc PV, Chipman EW (1990) Effect of molybdenum applications on plant molybdenum concentration and crop yields on sphagnum peat soils. Can J Soil Sci. 70:717-721.

IBGE - Instituto Brasileiro de Geografia e Estatística (2014) Produção Agrícola Municipal: culturas temporárias e perenes, v.41. IBGE, Rio de Janeiro. 100p.

Jião K, Jin W, Metzner H (1992) Determination of molybdenum in soils and plants using the polarographic adsorptive complex catalytic wave of Mo. Anal Chim Acta. 260:35-43.

Leão DSS, Peixoto VJV, Cecílio Filho AB (2008) Produtividade de melancia em diferentes níveis de adubação química e orgânica. Biosci J. 24:32-41.

Lima Neto IS, Guimarães IP, Batista PF, Aroucha EMM, Queiroz MA (2010) Qualidade de frutos de diferentes variedades de melancia provenientes de Mossoró - RN. Rev Caatinga. 23:14-20.

Mendel RR, Hansch R (2002) Molybdoenzymes and molybdenum cofactor in plants. J Exp Bot. 53(375):16891698.

Miranda FR, Oliveira JJG, Souza F (2004) Evapotranspiração máxima e coeficientes de cultivo para a cultura da 
melancia irrigada por gotejamento. Rev Cienc Agron. 35:36-43.

Mocellin RSP (2004) Princípios da adubação foliar: coletânea de dados e revisão bibliográfica. Omega, Canoas. 83p.

Naga Sivaiah K, Swain SK, Sandeep Varma V, Raju B (2013) Effect of Foliar Application of Micronutrients on Growth Parameters in Tomato (Lycopersicon esculentum Mill.). Discourse J Agric Food Sci. 1(10):146-151.

Pessoa ACS, Ribeiro AC, Chagas JM, Cassini TA (2000) Concentração foliar de molibdênio e exportação de nutrientes pelo feijoeiro "ouro negro" em resposta à adubação foliar com molibdênio. Rev Bras Ciênc Solo. 24:75-84.

Pires AA, Araújo GAA, Miranda GV, Berge PG, Ferreira ACB, Zampirolli PD, Leite UT (2004) Rendimento de grãos, componentes do rendimento e índice spad do feijoeiro (Phaseolus vulgaris L.) em função de época de aplicação e do parcelamento da aplicação foliar de molibdênio. Cienc Agrotec. 28:1092-1098.

Quaggio JA, Gallo PB, Owino-Gerroh C, Abreu MFH, Cantarella H (2004) Peanut response to lime and molybdenum application in low pH soils. Rev Bras Cienc Solo. 28:659-664.

Queiroga RCF, Puiatti M, Fontes PCR, Cecon PR, Finger FL (2007) Influência de doses de nitrogênio na produtividade e qualidade do melão Cantalupensis sob ambiente protegido. Hortic Bras. 25:550-556.

Ramos ARP, Dias RCS, Aragão CA (2009) Densidades de plantio na produtividade e qualidade de frutos de melancia. Hortic Bras. 27:560-564.
Resende GM, Alvarenga MAR, Yuri JE, Souza RJ (2012) Rendimento e teores de macronutrientes em alface americana em função de doses de nitrogênio e molibdênio. Hortic Bras. 30:373-378.

Ribeiro AC, Guimarães PTG, Alvarez VVH (1999) Recomendação para o uso de corretivos e fertilizantes em Minas Gerais, 5a Aproximação. CFSEMG, Viçosa. 359p.

Schwarz G, Mendel RR, Ribbe MW (2009) Molybdenum cofactors, enzymes and pathways. Nature. 460:839-847.

Silva ML, Queiróz MAB, Ferreira MAJF, Aragão CA (2007) Variabilidade genética de acessos de melancia coletados em três regiões do estado da Bahia. Rev Caatinga. 20:93100.

Taiz L, Zeiger E (2013) Fisiologia vegetal, 5rd edn. Artmed, Porto Alegre. 918p.

Tomatsu H, Takano J, Takahashi H, Watanabe-Takahashi A, Shibagaki N, Fujiwara T (2007). An Arabidopsis thaliana high-affinity molybdate transporter required for efficient uptake of molybdate from soil. J Exp Bot. 104:1880718812.

Vidigal SM, Pacheco DD, Costa EL, Facion CE (2009) Crescimento e acúmulo de macro e micronutrientes pela melancia em solo arenoso. Rev Ceres. 56:112-118.

Weng $B Q$, Huang DF, Xiong DZ, Wang YX, Luo T, Ying ZY, Wang HP (2009) Effects of molybdenum application on plant growth, molybdoenzyme activity and mesophyll cell ultrastructure of round leaf cassia in red soil. J Plant Nutr. 32:1941-1955. 